\title{
ACCIDENTAL FINDING OF DIROFILARIA REPENS IN DOG DURING THE QUALITY CONTROL OF SEMEN- CASE REPORT
}

\author{
Jelena Apić ${ }^{*}$, Tomislav Barna ${ }^{1}$, Marina Žekić Stošić ${ }^{1}$, \\ Aleksandar Milovanović́ ${ }^{1}$, Bojan Lukić 2 , Aleksandar Potkonjak ${ }^{3}$, Sara Savić ${ }^{1}$ \\ ${ }^{1}$ Scientific Veterinary Institute „Novi Sad“, Novi Sad, Republic of Serbia \\ ${ }^{2}$ PVA „Moj Veterinar“, Kać, Republic of Serbia \\ ${ }^{3}$ University of Novi Sad, Faculty of Agriculture, Department \\ of Veterinary Medicine, Novi Sad, Republic of Serbia
}

\section{Abstract}

A nine-year-old male dog of Doberman breed was taken to the laboratory for animal reproduction of the Scientific Veterinary Institute „Novi Sad" for semen quality control. The sample of the ejaculate was taken without difficulty; however, the sample contained a significant amount of fresh blood (total ejaculate volume was $5 \mathrm{ml}$ ). The assessment of semen quality from such sample was not possible because blood components mask the spermatozoa. Nevertheless, the sample of ejaculate drop was placed for microscopic observation and analysis. In the semen, a lot of blood cells and only a few spermatozoids (mostly not moving) were found; however, something else was observed - the presence of a live motile organism, longshaped, looking very much like a larval stage of a parasite Dirofilaria sp. Next day, the blood sample was taken for the analysis for dirofilariosis. The result of the ELISA test for Dirofilaria immitis antigen was negative indicating the absence of adult worms of Dirofilaria immitis. The result of modified Knott test showed the presence of larval stages of Dirofilaria repens.

Key words: male dog, semen quality, Dirofilaria repens, Knott test

\footnotetext{
${ }^{1}$ Corresponding author: jelena.a@niv.ns.ac.rs
} 


\title{
SLUČAJAN NALAZ DIROFILARIA REPENS TOKOM KONTROLE KVALITETA SEMENA PSA - PRIKAZ SLUČAJA
}

\author{
Jelena Apić ${ }^{1 *}$, Tomislav Barna ${ }^{1}$, Marina Žekić Stošić ${ }^{1}$, \\ Aleksandar Milovanović1 ${ }^{1}$ Bojan Lukić , Aleksandar Potkonjak², Sara Savić \\ ${ }^{1}$ Naučni institut za veterinarstvo „Novi Sad“, Novi Sad, Republika Srbija \\ ${ }^{2}$ PVA „Moj Veterinar“, Kać, Republika Srbija \\ ${ }^{3}$ Univerzitet u Novom Sadu, Poljoprivredni fakultet, Departman \\ za veterinarsku medicinu, Novi Sad, Republika Srbija.
}

\section{Kratak sadržaj}

Mužjak, rase Doberman, starosti devet godina, doveden je u laboratoriju za reprodukciju životinja, Naučnog instituta za veterinarstvo „Novi Sad“, radi redovne kontrole kvaliteta nativnog ejakulata. Procedura uzimanja ejakulata protekla je bez poteškoća. Međutim, dobijeni uzorak obilovao je znatnom količinom sveže krvi (ukupna količina ejakulata je bila $5 \mathrm{ml}$ ). Iz takvog uzorka nije moguće utvrditi validan kvalitet spermatozoida/ejakulata, jer krvne ćelije maskiraju spermatozoide. Ipak, iz znatiželje, uzorak kapi ejakulata je postavljen na mikroskopsku predmetnicu i mikroskopiran. U uzorku je pronađeno mnoštvo krvnih ćelija i tek po koji spermatozoid (uglavnom statičan), ali primećeno je nešto drugo - prisustvo žive forme, duguljastog oblika, veoma slično larvalnoj formi parazita Dirofilaria sp. Narednog dana, od istog psa je uzet uzorak periferne krvi radi analize na prisustvo diorfilarioze. Rezultati ELISA testa za antigen Dirofilaria immitis su bili negativni, što znači da adultnih formi parazita nema. Međutim, Knott testom utvrđeno je prisustvo larve Dirofilaria repens.

Ključne reči: mužjak, pas, kvalitet semena, Dirofilaria repens, Knott test

\section{INTRODUCTION}

Today, there is a growing demand for dogs of different breeds with superior genetic traits meaning the good exterior traits (constitution, color, temper, etc.) and health status in order to obtain a better offspring. This especially means the exclusion of hereditary diseases in these animals, such as dysplasia, 
blood coagulation disorders, diseases of the eye and the heart and other health problems that can cause a lot of pain to dogs and their owners / breeders, a lot of worry and economic costs.

Quality control of the semen in dogs has been showing increasing tendency among the dog keepers and breeders. More often, dog owners or breeders decide to test the semen of males before natural mating or artificial insemination of bitches. Over the time, dog breeding has become a lucrative business. Therefore, before the purchase of the male dog, some customers require from the breeder/owner to provide the semen analysis results obtained in accredited laboratories. Since 2016, Scientific Veterinary Institute „Novi Sad“ (NIV-NS), laboratory for domestic animal reproduction, is accredited for the assessment of animal semen quality, using CASA - Computer Assisted Sperm Analysis. On this occasion, the owner brought a dog to determine the quality of the semen and received a result on dirofilariosis.

Dirofilariosis is a vector borne disease, transmitted by a mosquito bite. Disease reservoirs are dogs and wild canids but the disease can also be transmitted to humans. Climatic, ecological, and many other factors have an influence on Dirofilaria sp. transmission. Dogs and wild canids can be definitive hosts for both types of Dirofilaria sp. On the other side, less well adapted or "aberrant" hosts are cats, wild felids and other mammalians (Potkonjak et al., 2020). There are two forms of dirofilariosis. One is caused by Dirofilaria immitis (Heartworm disease) where the adult worms migrate into the heart of a dog and cause serious problems, very often leading to the death of a dog. The other form caused by Dirofilaria repens is much milder form of the disease yet much more difficult to identify (Capelli et al., 2018). The disease caused by D. repens has almost no symptoms in dogs. Adult worms are imbedded under the skin and can persist there for a long time producing new larvae. Dogs can express nervousness or itchy feeling, if anything at all. Rarely, some cutaneous manifestations such as pruritus, dermal swelling and subcutaneous nodules can occur, or ocular conjunctivitis can be observed depending on the site where adult Dirofilaria are imbedded. It is important to emphasize that $D$. repens infection can be transmitted to people causing a zoonotic form of dirofilariosis (Genchi and Kramer, 2017).

Both forms of dirofilariosis have been identified and reported by many authors in Serbia (Tasić et al., 2003; Savić-Jevđenić et al., 2004; Savić et al., 2012; Spasojević Kosić et al., 2012; Krstić et al., 2017). Human cases of dirofilariosis have also been detected and reported in Serbia (Džamic et al., 2004; Krstić et al., 2017). 


\section{CASE PRESENTATION}

Male dog of Doberman breed, 9 years old, was brought in for semen collection and quality control. By observing the general condition of the dog, the weakness of posterior legs was noticed. The dog had a strong libido and the process of taking ejaculate passed without difficulty. However, the ejaculate was full of substantial amount of fresh blood (total ejaculate volume was 5 $\mathrm{ml}$ ). The assumption was that a small blood vessel was hurt during the process of semen intake. It was explained to the dog owner that it is not possible to assess the semen quality from that sample because the blood cells mask the spermatozoa and white blood cells weaken the sperm. They release substances, which destroy microorganisms that cause infection but also affect the sperm by destroying the sperm membrane, impair sperm movement, and damage sperm DNA. The result obtained from such kind of sample would not be valid. Nevertheless, the sample of ejaculate drop was placed under the microscope for observation and analysis (USB 200i light microscope at 100× magnification - Proiser, Paterna, Spain).

On the next day, blood sample was taken from the dog for analysis to dirofilariosis using modified Knott test and ELISA antigen test for Dirofilaria immitis. Modified Knott test was used for the detection of Dirofilaria sp. circulating microfilariae (Bazzocchi et al., 2008). Morphological characteristics of microfilariae (cephalic and caudal ends) were used in order to differentiate D.immitis and D.repens microfilariae of the two Dirofilaria species (Genchi et al., 2007). ELISA test was used for the detection of Dirofilaria immitis female adults' antigen.

The semen contained a lot of blood cells and just a few spermatozoids (mostly not moving). The whole semen sample was of dark red color resulting from excess blood in the sample. In the same semen sample, something else was seen - a live motile organism, long-shaped, looking very much like a larval stage of a parasite Dirofilaria sp. (Figure 1). The owner was immediately notified that his dog is suspected for dirofilariosis and that it would be recommendable to bring the animal for additional testing. The very next day, a blood sample was taken and analysed in the laboratory of Scientific Veterinary Institute „Novi Sad“. The result of the analysis performed using ELISA test for Dirofilaria immitis antigen was negative, indicating that there were no Dirofilaria immitis adult worms present. The result of modified Knott test revealed the presence of larval stages of Dirofilaria repens (Figure 2) moving in blood drop under the microscope. 
Arhiv veterinarske medicine, Vol. 13, No. 1, 111 - 119, 2020 Apić J. ... et al.: Accidental finding of Dirofilaria repens in dog...

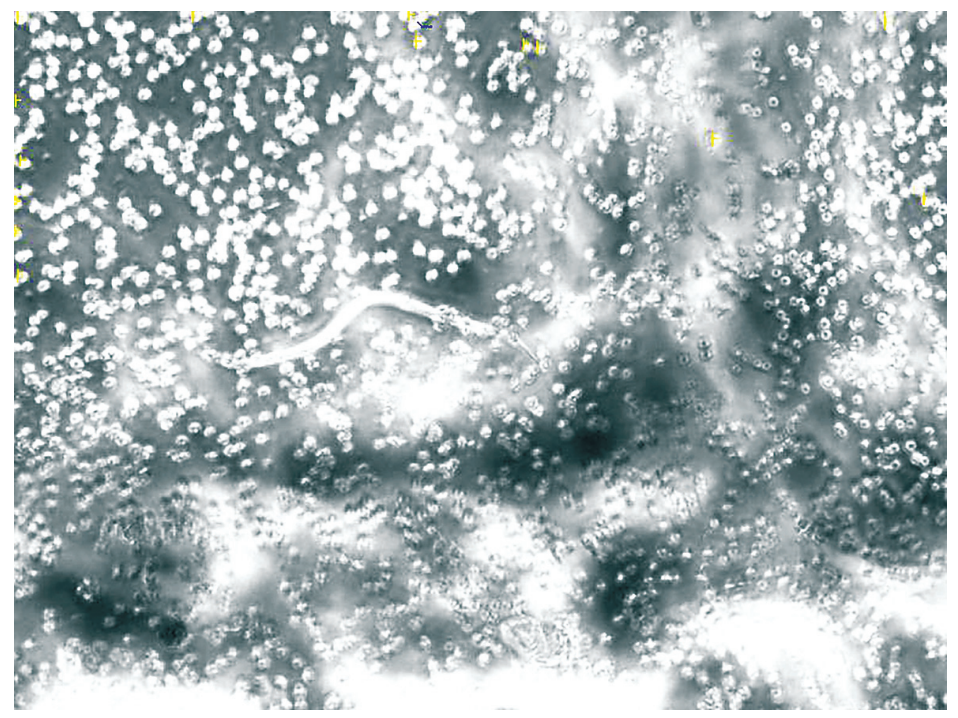

Figure 1. Photo of dog semen quality testing on CASA instrument.

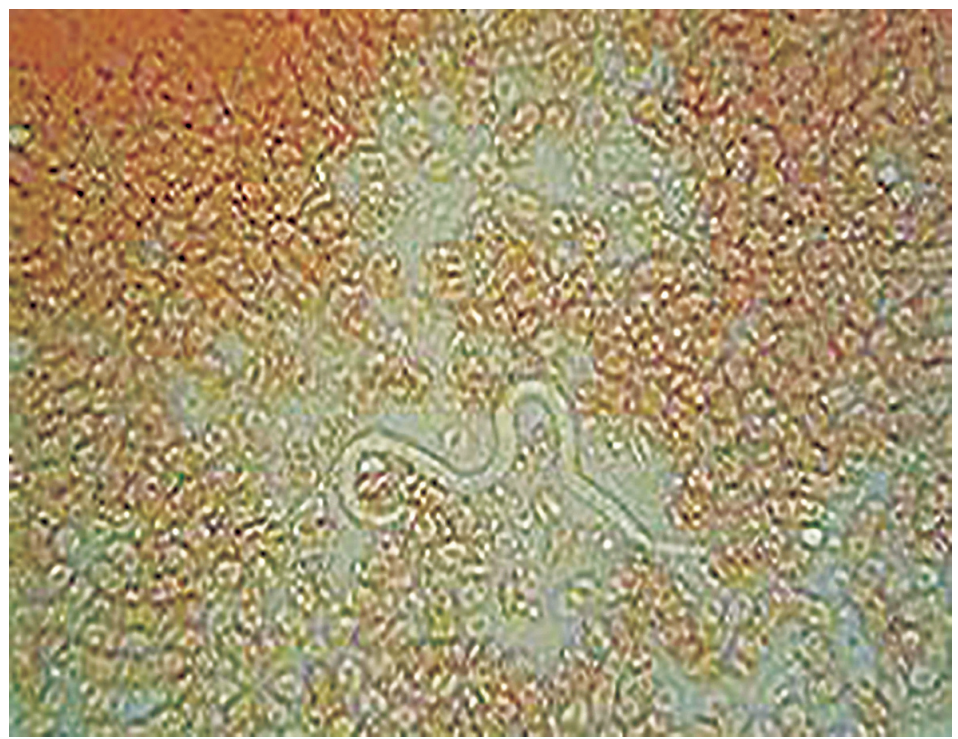

Figure 2. Photo of microscopic examination of dog blood - Knott test, $100 \times$ magnification 


\section{DISCUSSION}

Previous study on the prevalence of dirofilariosis in pet dogs in Novi Sad has shown the increase of Dirofilaria immitis infection and a decrease of infection with Dirofilaria repens (Spasojević Kosić et al., 2012, 2014) as compared to the first report on the prevalence of Dirofilaria repens infection (Tasić et al., 2008) and mixed infection with both parasites in dogs (Spasojević Kosić et al., 2014). Epidemiological importance of dirofilariosis in dogs caused by Dirofilaria repens lays in the zoonotic potential of the disease. The study of Spasojevic et al has shown that seroprevalence of Dirofilaria repens was dropping during the period from 2010 to 2016, while that of Dirofilaria immitis was rising in the same period (Spasojević Kosić et al., 2016).

A group of authors (Savić-Jevđenić et al., 2004) detected dirofilariosis caused by $D$. immitis in dogs in the region of Novi Sad, while another group of authors (Tasić et al., 2003) established dirofilariosis caused by D. repens, $D$. immitis and Dipetalonema reconditum in dogs in the same region. There is no doubt that the region from which the dog from our case study originates is endemic for dirofilariosis. Dirofilaria repens in dogs is pretty often neglected. A lot of the owners have only heard about Dirofilaria immitis as the causative agent of a heartworm disease because of its "deadly nature" for dogs. As compared with the disease caused by Dirofilaria immitis, dirofilariosis caused by Dirofilaria repens is most frequently asymptomatic and remains undiagnosed because the dog-owners do not recognize that there is something wrong. Another problem is the lack of commercial test for testing the dogs for the presence of Dirofilaria repens. There are no ELISA or fast/snap tests that can be used for Dirofilaria repens. Most commonly, the diagnosis is established unintentionally and the only option is to perform modified Knott test on blood sample for the identification or (when possible) a PCR for definite confirmation of the pathogen.

The reports of human ocular and subcutaneous dirofilariosis in Serbia published so far (Džamić et al., 2004) have confirmed the importance of dirofilariosis caused by Dirofilaria repens in human medicine in our country. Some of the authors identified adult $D$. repens worms in peritoneal location, that is, in the scrotum of dogs. During castration procedure, they were found protruding out from incised tunica vaginalis. The worm infected dogs had veins congestions, widening of the cavernous spaces of testes and epididymis, as well as thickened and enlarged epididymis along with interductal fibrosis. No significant effects on the process of spermatogenesis were observed (Ravindran et al., 2016). In a dog from our case study, there were no clinical symptoms of 
the same kind. However, the general condition of the dog was changed; the dog was nervous, uncomfortable, with week posterior legs. The semen sample showed very few spermatozoids with a very low, almost none activity. At this point, it cannot be stated whether the clinical status of the dog is a consequence of Dirofilaria repens infection. The dog will be subjected to therapy and observed during next several months in order to confirm the clinical status.

\section{AKNOWLEDGEMENT}

This work was supported by the Ministry of Science and Technological Development of the Republic of Serbia, grants TR 31084.

\section{Authors' contributions}

JA, SS, BL and AP made contributions to conception and design of the study, involved in data collection and drafting the manuscript. MŽ, AM and TB carried out the acquisition of sample, microscopic and serological tests and data analysis. SS revised the manuscript critically and together with JA prepared the final draft of the manuscript. All authors read and approved the final manuscript.

\section{Competing interests}

The author(s) declare that they have no competing interests.

\section{REFERENCES}

1. Bazzocchi C., Mortarino M., Grandi G., Kramer L.H., Genchi C., Bandi C., Genchi M., Sacchi L., McCall J.W. 2008. Combined ivermectin and doxycycline treatment has microfilaricidal and adulticidal activity against Dirofilaria immitis in experimantally infected dogs. International Journal of Parasitology, 38, 12, 1401-1410. doi: 10.1016/j.ijpara.2008.03.002.

2. Capelli G., Genchi C., Baneth G., Bourdeau P., Brianti E., Cardoso, Danesi P., Fuehrer H.P., Giannelli A., Ionică AM., Carla M., Modrý D., Montarsi F., Krücken J., Papadopoulos E., Petrić D., Pfeffer M., Savić S., Otranto D., Poppert S., Silaghi C. 2018. Recent advances on Dirofilaria repens in dogs and humans in Europe. Parasites Vectors, 11, 663. doi: 10.1186/s13071-018-3205-X.

3. Džamić A.M., Arsić-Arsenijević V., Radonjić I., Mitrović S., Marty P., Kranjčić-Zec I.F. 2004. Subcutaneous Dirofilaria repens infection of the eyelid in Serbia and Montenegro. Parasite, 11, 2, 239-40. 
4. Genchi C. and Kramer L. 2017. Subcutaneous dirofilariosis (Dirofilaria repens): an infection spreading throughout the old world. Parasites Vectors, 10, 2, 517. doi: 10.1186/s13071-017-2434-8.

5. Genchi C., Venco, L., Genchi M. 2007. Guideline for the laboratory diagnosis of canine and feline Dirofilaria infections. In Mappe Parassitologiche 8. Eds. C. Genchi, L. Rinaldi, G. Cringoli, Rolando Editore, Naples, 137-144.

6. Krstić M., Gabrielli S., Ignjatović M., Savić S., Cancrini G., Ranđelović G., Momčilović S., Stojnev S., Otašević S. 2017. An appraisal of canine and human cases reveals an endemic status of dirofilariosis in parts of Serbia. Molecular and Cellular Probes, 31, 37-41. doi:10.1016/j.mcp.2016.08.005.

7. Potkonjak A., Rojas A., Gutierezz R., Nachum-Biala Y., Kleinerman G., Savić S., Polaček V., Pušić I., Haruss S., Baneth G. 2020. Molecular survey of Dirofilaria species in stray dogs, red foxes and golden jackals from Vojvodina, Serbia. Comparative Immunology, Microbiology and Infectious Diseases, 68, 101409. doi: 10.1016/j.cimid.2019.101409.

8. Ravindran R., Julie B., Swapna S.A., Jerin F., Lenka D., Nandakumar S., Sabu S.M. 2016. Research Note Dirofilaria repens in scrotum of dogs. Tropical biomedicine, 33, 4, 842-846.

9. Savić S., Vidić B., Grgić Ž., Jurišić A., Curčić V., Ruzić M., Lolić Z. 2012. Vektorske zoonoze pasa u Vojvodini. Archives of Veterinary Medicine, 5, 1, 77-87. doi:10.46784/e-avm.v5i1.164.

10. Savić-Jevđenić S., Vidić B., Grgić Ž., Milovanović A. 2004. Brza dijagnostika dirofilarioze pasa u regionu Novog Sada. Veterinarski glasnik, 58, 5-6, 693-8.

11. Spasojević Kosić Lj., Lalošević V., Lalošević D., Simin S., Vasić I., Kuruca Lj. 2012. Prevalence of dirofilariosis in pet dogs in Novi Sad. Contemporary agriculture, 61, 3-4, 247-254.

12. Spasojević Kosić Lj., Simin S., Lalošević V., Lalošević D., Kuruca Lj., Nikolić S., Nerac D. 2014: Updating the prevalence of dirofilariosis in pet dogs in Novi Sad, Vojvodina, Serbia, Contemporary agriculture, 63, 4-5, 487-493.

13. Spasojević Kosić Lj., Lalošević V., Simin S., Kuruca Lj. 2016. Dirofilariosis and Angiostrongilosis in pet and hunting dogs in Novi Sad, Vojvodina, Serbia. Archives of Veterinary Medicine, 9, 2, 53-62. doi: 10.46784/e-avm. v9i2.89.

14. Tasić A., Katić Radivojević S., Klun I., Mišić Z., Ilić T., Dimitrijević S. 2003. Prevalencija filarioza pasa u nekim područjima Vojvodine. U Zbornik radova i kratkih sadržaja, 15. Savetovanje veterinara Srbije. Zlatibor, Srpsko veterinarsko društvo, 172. 
15. Tasić A., Rossi L., Tasić S., Miladinović-Tasić N., Ilić T., Dimitrijević S. 2008. Survey of canine dirofilariasis in Vojvodina, Serbia. Parasitology Research, 103, 1297-1302. doi: 10.1007/s00436-008-1132-z.

Submitted: 16.01.2020.

Accepted: 16.06.2020. 